\title{
Pneumopericardium due to bronchopericardial fistula in a patient with lung cancer
}

\author{
Joana Lages, ${ }^{1}$ Cátia Costa Oliveira, ${ }^{2}$ Catarina Lacerda ${ }^{1}$
}

'Pneumology Department, Hospital de Braga, Braga, Portugal

${ }^{2}$ Cardiology Department, Hospital de Braga, Braga, Portugal

\section{Correspondence to}

Dr Joana Lages,

joana.vale.lages@gmail.com

Accepted 20 September 2018

\section{DESCRIPTION}

Documented cases of pneumopericardium in patients with lung cancer are extremely rare.

We report the case of a 66-year-old man with a 45 pack-year smoking history and an Eastern Cooperative Oncology Group performance status 4. He presented with dyspnoea and chest pain in the last 2 hours. There were no signs of cardiac tamponade present.

CT angiography of the chest revealed a $78 \mathrm{~mm}$ right pulmonary mass containing small areas with gas density and a pneumopericardium of $28 \mathrm{~mm}$ in maximum thickness (figure 1). Transthoracic echocardiography showed the air gap sign, identified as the loss of signal during the systolic phase presented in patients with pneumopericardium. Bronchofibroscopy showed extensive infiltration and destruction of the carina bronchial wall and of the main bronchi by malignancy and endobronchial disease (figure 2). Endobronchial biopsies revealed an invasive squamous cell carcinoma.

Pneumopericardium due to lung cancer is proposed to be caused by the formation of a bronchopericardial fistula through direct pericardial invasion of a necrotic tumour, iatrogenic trauma caused by procedures or rupture of a bulla into the pericardium through a necrotic focus. ${ }^{12}$

In this case, the presence of the pneumopericardium seems to be related to the formation of bronchopericardial fistula with direct pericardial invasion by the necrotic tumour. Due to the low-performance status and the high risk of complications, the patient was not eligible for a target treatment, such as thoracic radiotherapy

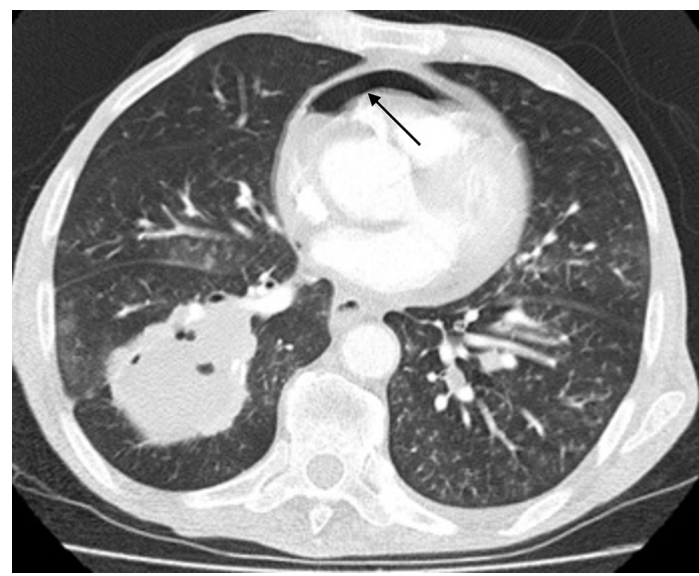

Figure $1 \mathrm{CT}$ angiography of the chest showing a large tumour in the right lung and a pneumopericardium (arrow) anterior to the heart.
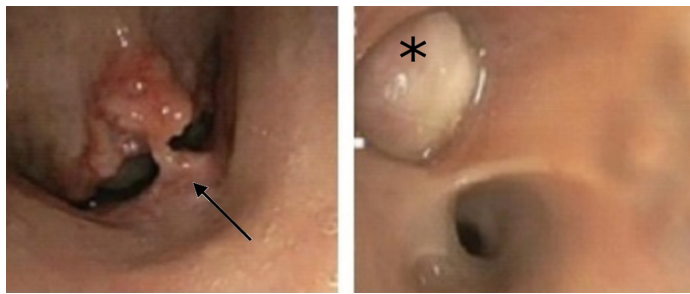

Figure 2 Bronchofibroscopy revealing extensive signs of cancer invasion of the bronchial tree with destruction of the carina bronchial wall (arrow) and of the main bronchi. It also shows the presence of the endobronchial tumour on the lateral basal segment of the right inferior lobar bronchus (asterisk).

or bronchial stent placement. The patient was clinically stable so conservative and symptomatic treatment was performed. This included high-flow oxygen therapy, analgesics, antibiotics and continuous monitoring of any signs and symptoms of cardiac tamponade.

During the hospital admission, the patient's condition deteriorated rapidly and palliative treatment was performed. The patient died after 3 weeks.

\section{Learning points}

When facing a patient with pneumopericardium and lung cancer, clinicians should consider the formation of a bronchopericardial fistula by direct pericardial invasion of a necrotic tumour as a differential diagnosis.

- Patients with small, stable and asymptomatic pneumopericardium may be treated conservatively with close monitoring to prevent escalation to a cardiac tamponade.

Contributors $\mathrm{J}$ has written the manuscript. The manuscript was reviewed and corrected by CCO and CL.

Funding The authors have not declared a specific grant for this research from any funding agency in the public, commercial or not-for-profit sectors.

Competing interests None declared.

Patient consent Next of kin consent obtained.

Provenance and peer review Not commissioned; externally peer reviewed.

\section{REFERENCES}

1 Al-Taweel A, Ayub A, Huang CY, et al. Pneumopericardium leading to cardiac tamponade in a patient with lung cancer. Thorac Cardiovasc Surg Rep 2016:5:13-15.

2 Kara J, Klimesova S, Pauk N. Neumomediastino y neumopericardio en un paciente con cáncer de pulmón espinocelular. Archivos de Bronconeumología 2015;51:249-50. 
Copyright 2018 BMJ Publishing Group. All rights reserved. For permission to reuse any of this content visit http://group.bmj.com/group/rights-licensing/permissions.

BMJ Case Report Fellows may re-use this article for personal use and teaching without any further permission.

Become a Fellow of BMJ Case Reports today and you can:

- Submit as many cases as you like

- Enjoy fast sympathetic peer review and rapid publication of accepted articles

Access all the published articles

- Re-use any of the published material for personal use and teaching without further permission

For information on Institutional Fellowships contact consortiasales@bmjgroup.com

Visit casereports.bmj.com for more articles like this and to become a Fellow 